\title{
Inhibitory Smads and bone morphogenetic protein (BMP) modulate anterior photoreceptor cell number during planarian eye regeneration
}

\author{
ALEJANDRO GONZÁLEZ-SASTRE, Ma DOLORES MOLINA**\# and EMILI SALÓ* \\ Departament de Genètica, Facultat de Biologia, Universitat de Barcelona and Institut de Biomedicina de la \\ Universitat de Barcelona (IBUB), Universitat de Barcelona, Barcelona, Catalunya, Spain
}

\begin{abstract}
Planarians represent an excellent model to study the processes of body axis and organ re-specification during regeneration. Previous studies have revealed a conserved role for the bone morphogenetic protein (BMP) pathway and its intracellular mediators Smad1/5/8 and Smad4 in planarian dorsoventral (DV) axis re-establishment. In an attempt to gain further insight into the role of this signalling pathway in planarians, we have isolated and functionally characterized the inhibitory Smads (I-Smads) in Schmidtea mediterranea. Two I-Smad homologues have been identified: Smed-smad6/7-1 and Smed-smad6/7-2. Expression of smad6/7-1 was detected in the parenchyma, while smad6/7-2 was found to be expressed in the central nervous system and the eyes. Neither single smad6/7-1 and smad6/7-2 nor double smad6/7-1,-2 silencing gave rise to any apparent disruption of the DV axis. However, both regenerating and intact smad6/7-2 (RNAi) planarians showed defects in eye morphogenesis and displayed small, rounded eyes that lacked the anterior subpopulation of photoreceptor cells. The number of pigment cells was also reduced in these animals at later stages of regeneration. In contrast, after low doses of Smed-bmp(RNAi), planarians regenerated larger eyes in which the anterior subpopulation of photoreceptor cells was expanded. Our results suggest that Smed-smad6/7-2 and Smed-bmp control the re-specification and maintenance of anterior photoreceptor cell number in $\mathbf{S}$. mediterranea.
\end{abstract}

KEY WORDS: planarian, regeneration, BMP pathway, eye, I-Smad

\section{Introduction}

Planarians (order Tricladida) are free-living platyhelminths that are well known for their ability to regenerate and restore their polarity and missing organs in a short period of time (reviewed in Saló, 2006).

The light-sensing organs, the eyes, are well-defined sensory structures in planarians and can be easily recognized as two dark spots on the anterior-dorsal region of the animal (reviewed in Saló and Batistoni, 2008). Planarian eyes are composed of two cell types: photoreceptor and pigment cells. Photoreceptors are bipolar neurons. Their axons extend towards the dorsomedial side of the cephalic ganglia and form a partial optic chiasm, which integrates photosensory inputs from both sides of the animal (Okamoto et al., 2005). The dendrites generally have a rhabdomeric structure, a regularly ordered microvilli assembly, where opsin protein accumulates (Orii et al., 1998). The pigment cells form an eyecup which surrounds the rhabdomeres. Recently, the analysis of several prohormone genes revealed the existence of at least three different subpopulations within the photoreceptor cells. Specifically, it was shown that neuropeptide prohormone genes eye53-1 and npp-12 are expressed in anterior photoreceptor neurons, whereas eye532 is expressed in the dorsal posterior subpopulation and $\mathrm{mpl}-2$ is expressed in both dorsal and ventral posterior subpopulation

Abbreviations used in this paper: BMP, bone morphogenetic protein; DV, dorsoventral; FISH, fluorescent in situ hybridization; I-Smad, inhibitory Smad; MH, Mad homology; RNAi, RNA interference.

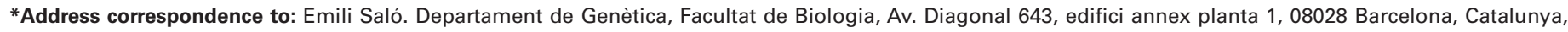

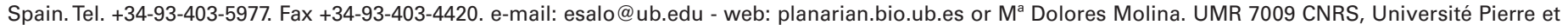
Marie Curie (Paris VI), Observatoire Océanologique de Villefranche-sur-Mer, 06230 Villefranche-sur-mer, France. Tel. +33-49-376-3785. Fax +33-49-376-3792.

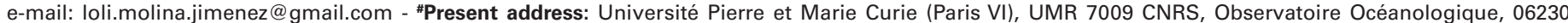
Villefranche-sur-mer, France.
}

Supplementary Material (1 figure) for this paper is available at: http://dx.doi.org/10.1387/ijdb.123494ag 
(Collins et al., 2010).

Planarians regenerate new eyes following head amputation (reviewed in Saló and Batistoni, 2008). Regeneration of the planarian eye employs the same basic genetic network that regulates vertebrate eye development, although the mechanism is Pax6 independent (Pineda et al., 2000, 2002; Mannini et al., 2004). Recently, several novel regulators of planarian eye regeneration have been identified (Lapan and Reddien, 2011; Fraguas et al., 2011).

The Bone Morphogenetic Protein (BMP) family of secreted signalling molecules plays multiple roles during metazoan development and regeneration. For instance, BMP signalling is essential in processes such as establishment of the dorsoventral (DV) axis (reviewed in Little and Mullins, 2006) and patterning of the central nervous system (CNS; reviewed in Liu and Niswander, 2005). It also plays a key role during development and regeneration of the retina (Murali et al., 2004), the lens (Sjödal et al., 2007) and the ciliary body (Zhao et al., 2002) of the vertebrate eye, and enhances photoreceptor fate specification during zebrafish pineal gland determination (Quillien et al., 2011).

Smads are the main downstream mediators of the BMP signalling pathway (reviewed in Wrana, 2000). Three main classes of Smad proteins have been identified according to their structure and function: R-Smads or receptor-associated Smads (Smad1/5/8), co-Smads or common Smads (Smad4) and I-Smads or inhibitory Smads (Smad6/7). Smad proteins are characterized by the presence of Mad homology $(\mathrm{MH})$ domains. R-Smads and co-Smad contain two MH domains: an amino terminal $\mathrm{MH} 1$ domain, which binds to DNA and confers the transcriptional activity, and a carboxy-terminal $\mathrm{MH} 2$ domain, which is involved in protein-protein interactions. ISmads only contain the MH2 domain and, consequently, act as inhibitors of signalling (reviewed in Wrana, 2000). In addition to $\mathrm{MH}$ domains, R-Smads contain a C-terminal consensus sequence that is phosphorylated by the receptor.

In recent years, several studies have shown that BMP signalling is essential for correct blastema formation and specification of the planarian DV axis (reviewed in Molina et al., 2011b). In addition to DV phenotypes, inhibition of different elements of the pathway gives rise to abnormal eye regeneration (Reddien et al., 2005a, 2007; Molina et al., 2007, 2011a; Orii and Watanabe, 2007). For instance, aberrant projections of the visual axons are regenerated after bmp, smad1, smad4 or tolloid inhibition (Reddien et al., 2005a, 2007; Molina et al., 2007), while inhibition of bmpand smad4 also produces duplicated and supernumerary eyes, respectively (Reddien et al., 2007; Molina et al., 2007; Orii and Watanabe, 2007).

In an attempt to gain further insight into the role of BMP signalling in planarians, we isolated and functionally characterized two I-Smad genes in Schmidtea mediterranea: Smed-smad6/7-1 and Smed-smad6/7-2. Here we show that smad6/7-2 silencing results in small, rounded eyes that lack the anterior subpopulation of photoreceptor cells. Remarkably, low doses of RNAi for the extracellular ligand BMP produced elongated eyes with an expanded anterior subpopulation of photoreceptor cells. Taken together, our data suggest that the BMP pathway regulates the number of anterior visual cells.

\section{Results}

\section{Identification and isolation of S. mediterranea inhibitory Smads}

To isolate I-Smad homologues in planarians, I-Smad proteins from several animals were used to perform in silico searches of $S$. mediterraneagenomic (Washington University Sequencing Center, available at http://www.genome.wustl.edu) and 454 transcriptomic (Abril etal., 2010) databases. Two full-length homologues containing open reading frames of 340 and 182 amino acids were obtained. The predicted protein structures of both identified sequences contained the unique $\mathrm{MH} 2$ carboxy-terminal domain that defines I-Smads. These genes were therefore named Smed-smad6/7-1 and Smed-smad6/7-2, respectively. It is important to notice, however, that $s m a d 6 / 7-2$ contains a significantly shorter coding region than smad6/7-1 and homologues of I-Smads found in other organisms.

\section{Expression pattern of Smed-smad6/7-1 and Smed-smad6/7-2}

Whole-mount in situ hybridization performed in intact and regenerating animals revealed different expression patterns for $S$. mediterranea I-smads. In intact animals, smad6/7-1 was expressed throughout the parenchyma (Fig. $1 \mathrm{~A}$ ), in a pattern that resembles the distribution of the planarian stem cells, the neoblasts (reviewed in Handberg-Thorsager et al., 2008). The neoblasts are the only proliferative cells found in the animal and are specifically eliminated after X-ray irradiation (Dubois, 1949). Consequently, the expression
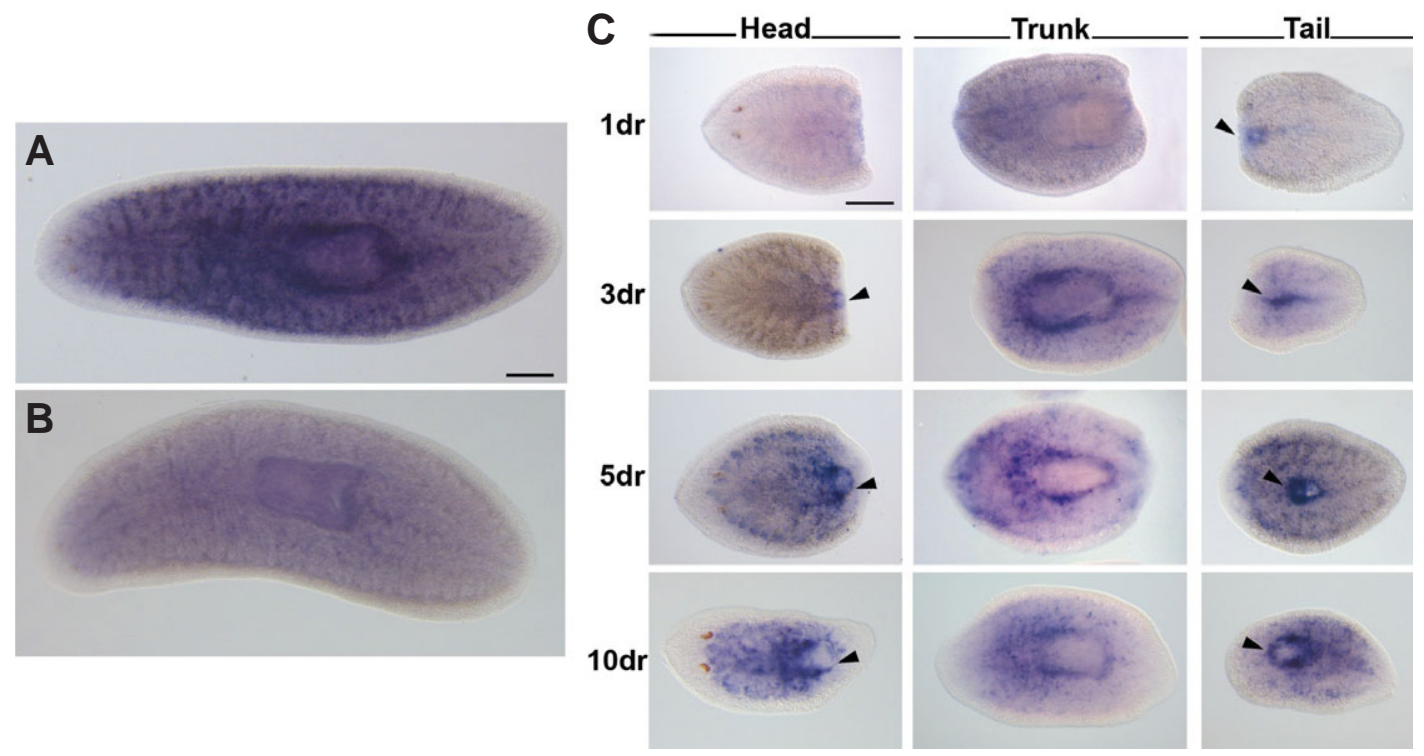

Fig. 1. Expression pattern of Smed-smad6/7-1 in intact and regenerating planarians. (A) Expression of Smedsmad6/7-1 in the parenchyma of intact planarians. (B) Down-regulation of smad6/7-1 expression 3 days after irradiation at $100 \mathrm{~Gy}$. (C) Expression of Smed-smad6/7-1 during regeneration. Arrowheads point to the newly regenerated pharyngeal cavity. Anterior is to the left. dr, days of regeneration. Scale bars: $350 \mu \mathrm{m}$. 


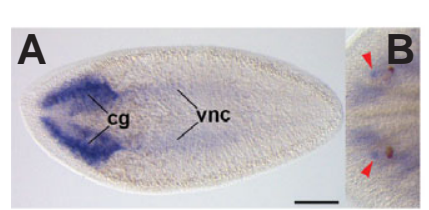

G
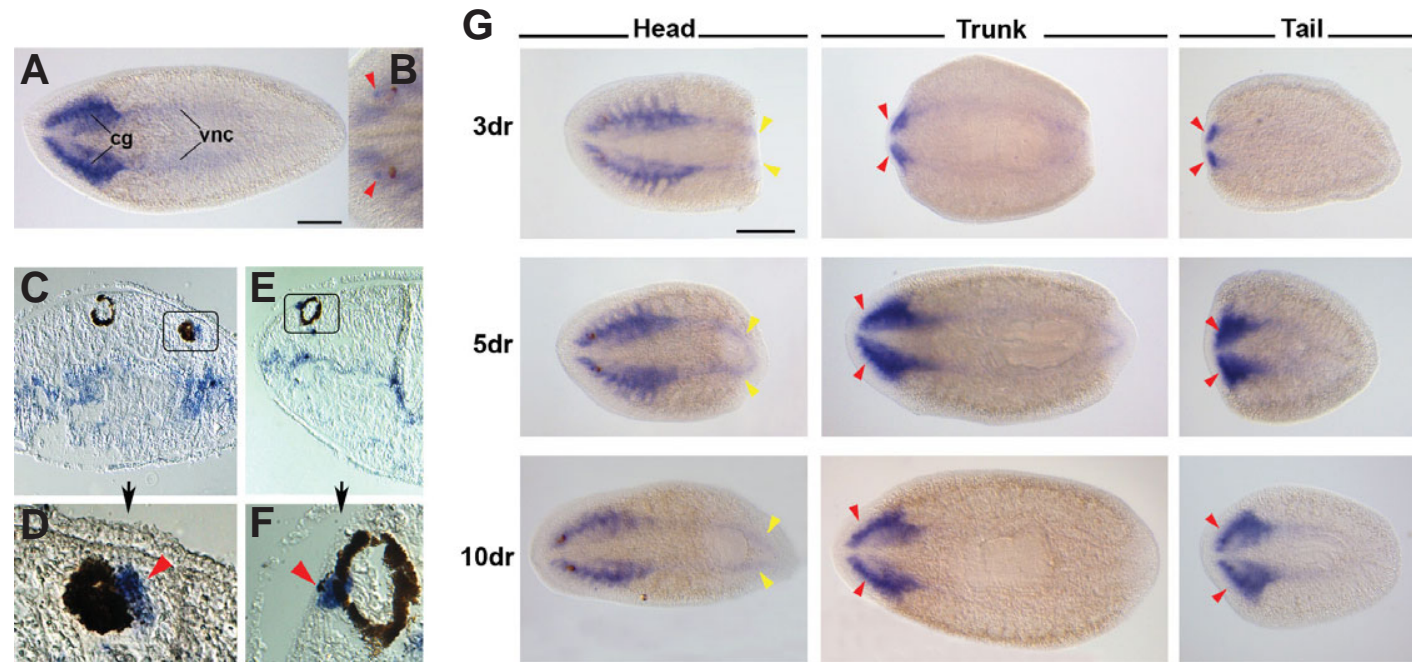
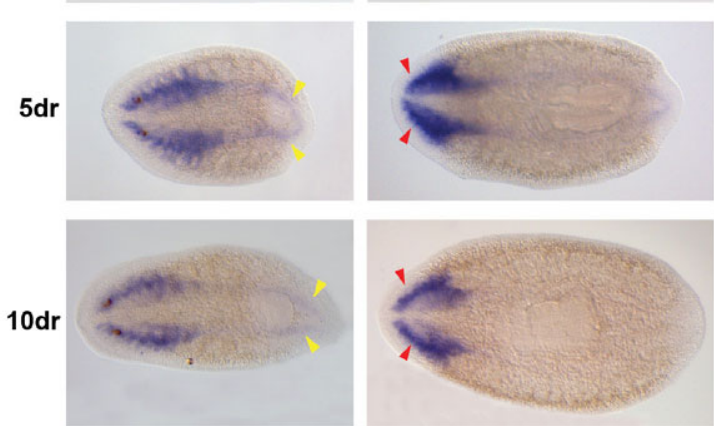

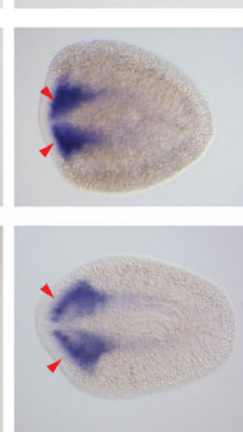

Fig. 2. Expression pattern of Smed-smad6/7-2 in intact and regenerating planarians. (A-F) Intact planarians. (A) Expression ofSmed-smad6/7-2 in the cephalic ganglia $(\mathrm{cg})$ and the ventral nerve cords (vnc). (B) Expression of Smed-smad6/7-2 in the eyes, in an anterior subpopulation of photoreceptor cells (arrowheads). (C-F) Expression of Smed-smad6/7-2 in the eyes (arrowheads in D,F). (G) Expression of Smed-smad6/7-2 during regeneration. Red arrowheads point to the newly regenerated brain. Yellow arrowheads point to the newly regenerated nerve cords in posteriorly regenerating head fragments. Ventral views. (C,D) Transverse section. (E,F) Sagittal section. Anterior is to the left in $(A, B, E-G)$. Dorsal is to the top in (C-F). dr, days of regeneration. Scale bars: $(A, G) 350 \mu \mathrm{m} ;(B) 175 \mu \mathrm{m} ;(C, E) 150 \mu \mathrm{m} ;(D, F) 40 \mu \mathrm{m}$.

of neoblast markers is down-regulated upon irradiation (Eisenhoffer et al., 2008). To determine whether smad6/7-1 is expressed in neoblasts, we performed whole-mount in situhybridization in irradiated planarians. Strong down-regulation of smad6/7-1 expression was observed 3 days after X-ray irradiation (Fig. 1B), suggesting that this gene is expressed in neoblasts. During regeneration, high levels of smad6/7-1 expression were detected around the newly formed pharyngeal cavity (arrowheads in Fig. 1C). This expression was induced during both head and tail regeneration (Fig. 1C).

In intact animals, smad6/7-2 was expressed in the CNS, in both the ventral nerve cords and the cephalic ganglia (Fig. 2A). Moreover, smad6/7-2 expression was observed in the eyes, in an anterior subpopulation of photoreceptor cells (Fig. 2 B-F). During anterior regeneration, newly formed eyes started expressing smad6/7-2 at day 5 (data not shown), whereas cephalic ganglia started expressing smad6/7-2 at day 3 (red arrowheads in Fig. $2 \mathrm{G})$. At this time, expression of smad6/7-2 was also detected in newly regenerated nerve cords in posteriorly regenerating head fragments (yellow arrowheads in Fig. 2G).

\section{Smad6/7-2(RNAi) planarians have smaller rounded eyes}

To analyze the role of I-Smads during planarian regeneration, we performed RNAi knockdown experiments. Following double-stranded RNA injection, planarians were amputated pre- and post-pharyngeally and the resulting fragments were allowed to regenerate. Unless otherwise indicated, all the results presented here refer to regenerating trunk pieces that simultaneously regenerate anterior and posterior structures.

Loss of function of smad6/7-1 did not result in any discernible morphological or molecular defects. Similar to control organisms, smad6/7-1(RNAi) planarians regenerated well-formed blastemas that correctly differentiated eyes, cephalic ganglia and digestive system (data not shown). On the other hand, compared to control animals, smad6/7-2(RNAi) planarians regenerated small, rounded eyes (Fig. 3 A-B). In both control and smad6/7-2(RNAi) planarians, regenerated eyes initially appeared within the anterior blastema as two dark rounded spots at 4-5 days of regeneration. Starting from day 7-8 postamputation, however, when the pigmented spots of control organisms elongated anteroposteriorly, the eyes of smad6/72-silenced planarians remained rounded (Fig. 3 A-B).

Neither smad6/7-1 nor smad6/7-2silencing resulted in apparent morphological or molecular defects related to blastema formation and DV axis re-establishment. Thus, general DV morphology of the animal seemed normal and the expression of ventral and dorsal markers did not seem affected (data not shown). This apparent lack of a DV phenotype was not caused by redundant function of I-Smads, since even after several rounds of smad6/7$1,-2$ co-silencing, planarians correctly re-specified their DV axis.
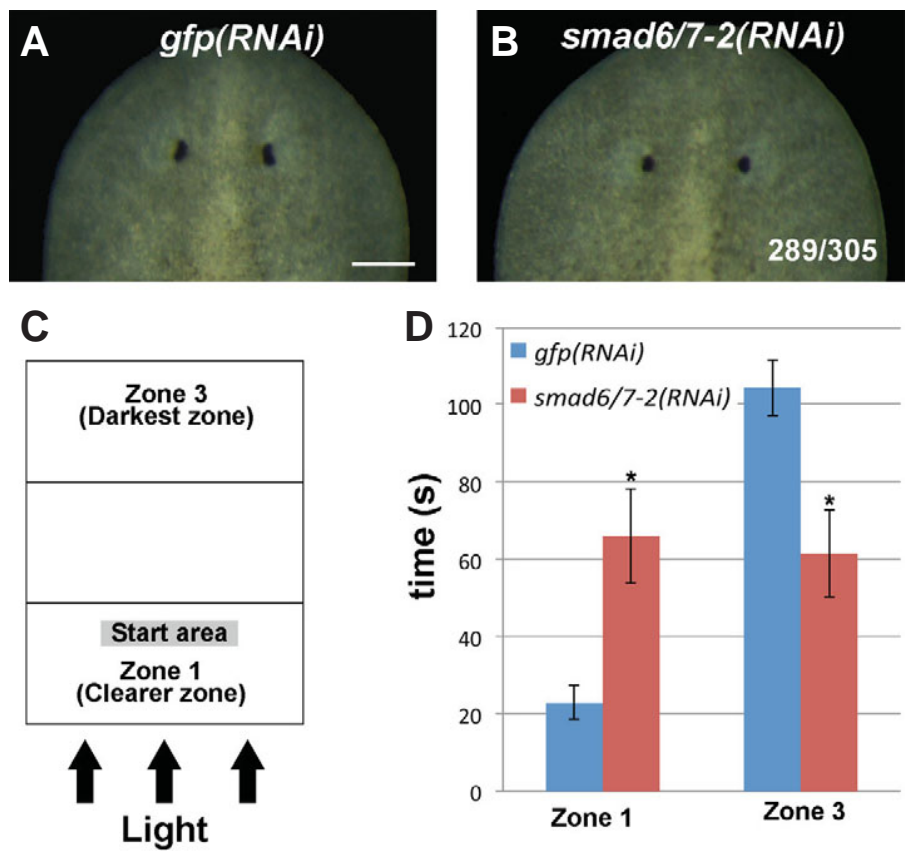

Fig. 3. Morphological and behavioural phenotypes in Smed-smad6/72(RNAi) animals. (A,B) Live control and smad6/7-2(RNAi) planarians at 10 days of regeneration. Anterior is to the top. (C,D) Phototactic assay. (C) Diagram of the container. (D) Graphical representation of the time that control and smad6/7-2(RNAi) planarians spend in the different sectors. ${ }^{*} p<0.01$ (t test). Scale bar: $175 \mu \mathrm{m}$. 
smad6/7-2(RNAi) planarians have abnormal negative phototactic behaviour

When exposed to light, planarians display a distinctive lightavoidance behaviour known as negative phototaxis. In order to determine whether smad6/7-2 silencing alters normal planarian negative phototactic behaviour, animals were exposed to a light gradient and their behaviour filmed and analysed. Control animals moved rapidly away from light and spent most of their time in the darkest zone (Zone 3) of the container. In contrast, smad6/7-2(RNAi) organisms displayed a statistically significant reduction in negative phototaxis and stayed longer in the clearest zone (Zone 1). Thus, although smad6/7-2(RNAi) animals moved normally, they turned more often and spent more time in the clearest zone than
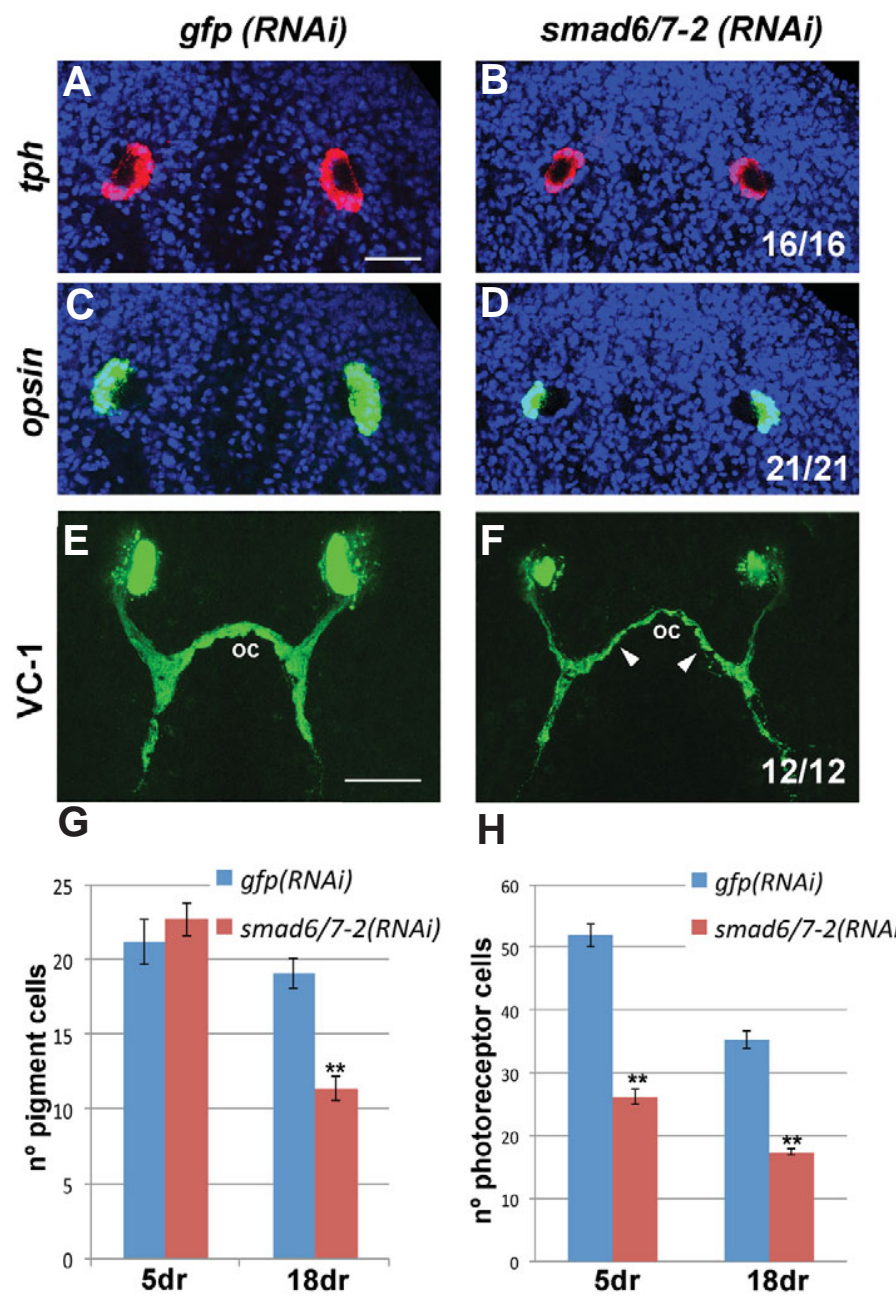

Fig. 4.Analysis of pigment and photoreceptor cells in smad6/7-2(RNAi) planarians. (A,B) Fluorescent in situ hybridization against tph, a marker of pigment cells. Note the smaller expression domain in smad6/7-2(RNAi) animals. (C,D) Fluorescent in situ hybridization against opsin, a marker of photoreceptor cells. Note the smaller expression domain in smad6/7-2(RNAi) animals. (E,F) Immunofluorescence against arrestin (VC-1), labelling the photoreceptor cells and the optic chiasm (oc). Arrowheads indicate the thinner optic chiasm in smad6/7-2(RNAi) animals. (G,H) Graphical representation of the total number of pigment $(G)$ and photoreceptor $(H)$ cells at 5 and 18 days of regeneration in control and Smed-smad6/7-2(RNAi) planarians. ${ }^{*} p<0.001$ (t test). (A-D) 10 days of regeneration. (E, F) 18 days of regeneration. Anterior is to the top. Scale bar: $50 \mu \mathrm{m}$. control animals (mean \pm SEM of $23.1 \pm 4.4$ seconds in controls $[n=15]$ versus $66.2 \pm 12.2$ seconds in smad6/7-2(RNAi) animals $[\mathrm{n}=17])$, while control animals spent more time in the darkest zone than smad6/7-2(RNAi) animals (104.5 \pm 7.2 seconds in controls $[\mathrm{n}=15]$ versus $61.7 \pm 11.3$ seconds in smad6/7-2(RNAi) animals $[\mathrm{n}=15])$ (Fig. 3 C-D).

\section{smad6/7-2 silencing results in reduced numbers of eye pho- toreceptor and pigment cells}

To analyse the small, rounded eyes associated with smad6/7-2 loss of function, we examined the expression pattern of specific markers of pigment and photoreceptor cells. Pigment cells were visualized and quantified by combining nuclear staining and fluorescent in situ hybridization (FISH) against Smed-tph (Fraguas et al., 2011) (Fig. 4 A-B). In agreement with the normal morphological appearance of the pigmented eye cup at initial stages of regeneration, no significant differences in the number of Smedtph-expressing pigment cells were observed between control and smad6/7-2(RNAi) planarians at 5 days $(21.2 \pm 1.5$ cells in controls $[\mathrm{n}=5$ ] versus $22.7 \pm 1.1$ cells in smad6/7-2(RNAi) eyes [n=6]) (Fig. $4 \mathrm{G})$. In contrast, as regeneration proceeded, the small rounded eyecup of smad6/7-2-silenced animals had a significantly reduced number of pigment cells compared to control organisms $(19.1 \pm 1.0$ cells in controls $[\mathrm{n}=7$ ] versus $11.4 \pm 0.8$ cells in smad6/7-2(RNAi) eyes [n=7]) (Fig. 4G).

To visualize and quantify photoreceptor cells, we performed FISH against Smed-opsin (Sánchez Alvarado and Newmark 1999) (Fig. 4 C-D). Remarkably, smad6/7-2-silenced planarians already had a significant reduction in the total number of Smed-opsin-labelled photoreceptor cells at 5 days of regeneration $\left(52.0_{ \pm} 1.1\right.$ cells in controls [ $\mathrm{n}=12$ ] versus $26.3 \pm 1.2$ cells in smad6/7-2 RNAi-treated eyes $[n=16])(F i g .4 H)$. The reduction in the number of photoreceptor cells in smad6/7-2(RNAi) animals was still apparent at 18 days of regeneration $(35.4 \pm 1.4$ cells in controls $[n=20]$ versus $17.5 \pm 0.5$ cells in smad6/7-2(RNAi) eyes [n=17]) (Fig. 4H).

Photoreceptor cells are bipolar neurons that project axons towards the ipsilateral side of the cephalic ganglia or cross to the contralateral side and connect to the opposite eye and cephalic ganglia, producing an optic chiasm (Cebrià and Newmark, 2005; Okamoto et al., 2005, Sakai et al., 2000, Fig. 4E). Immunostaining with VC-1, an antibody against the arrestin protein that specifically recognizes the photoreceptor cells, allows visualization of this stereotypical pattern of axonal projections (Sakai et al., 2000; Okamoto et al., 2005). Interestingly, despite the reduced number of photoreceptor cells, smad6/7-2-silenced animals displayed normal stereotypical axonal projections according to VC-1 immunostaining (Fig. 4F). However, those axonal projections were thinner compared to control organisms (arrowheads in Fig. 4F).

These data indicate that, although reduced, both pigment and photoreceptor cells are present in the smaller eye obtained after smad6/7-2 silencing. Moreover, they reveal an earlier effect on photoreceptor cells followed by a later decrease in pigment cells.

\section{Anterior photoreceptor cells disappears after smad6/7-2 silencing}

Several molecular markers for different populations of eye photoreceptor cells have recently been identified (Collins et al., 2010). To assess whether the decrease in the number of photoreceptor cells observed after smad6/7-2 silencing differentially affects these 


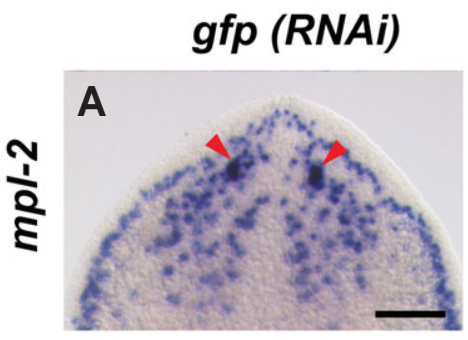

smad6/7-2 (RNAi)
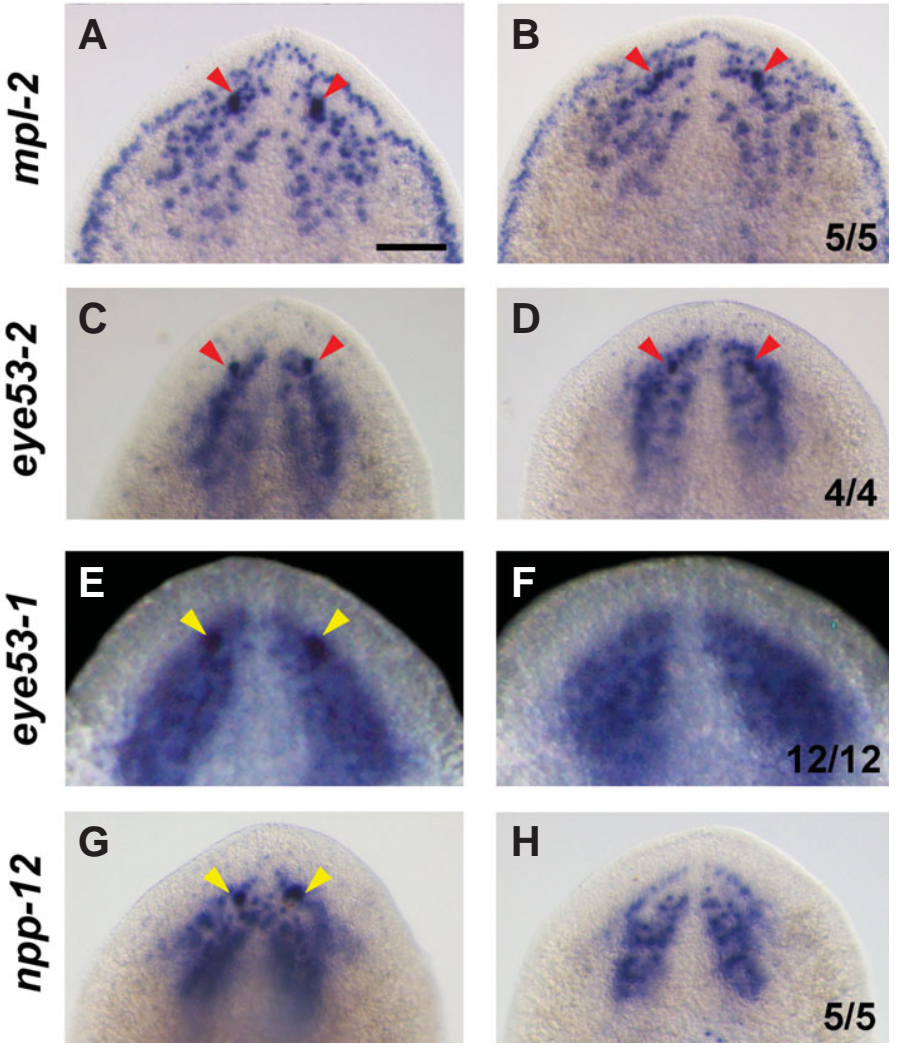

Fig. 5 (Left). Analysis of markers for anterior and posterior photoreceptor cells. (A-D) Expression of the posterior markers Smed-mpl-2 (arrowheads in A,B) and Smed-eye53-2 (arrowheads in C,D) in control and smad6/7-2(RNAi) planarians. (E-H) The expression of the anterior markers Smed-eye53-1 (arrowheads in E) and Smed-npp-12 (arrowheads in G) disappears in smad6/7-2(RNAi) animals. Animals are shown at 12 days of regeneration. Anterior is to the top. Scale bar, $150 \mu \mathrm{m}$.

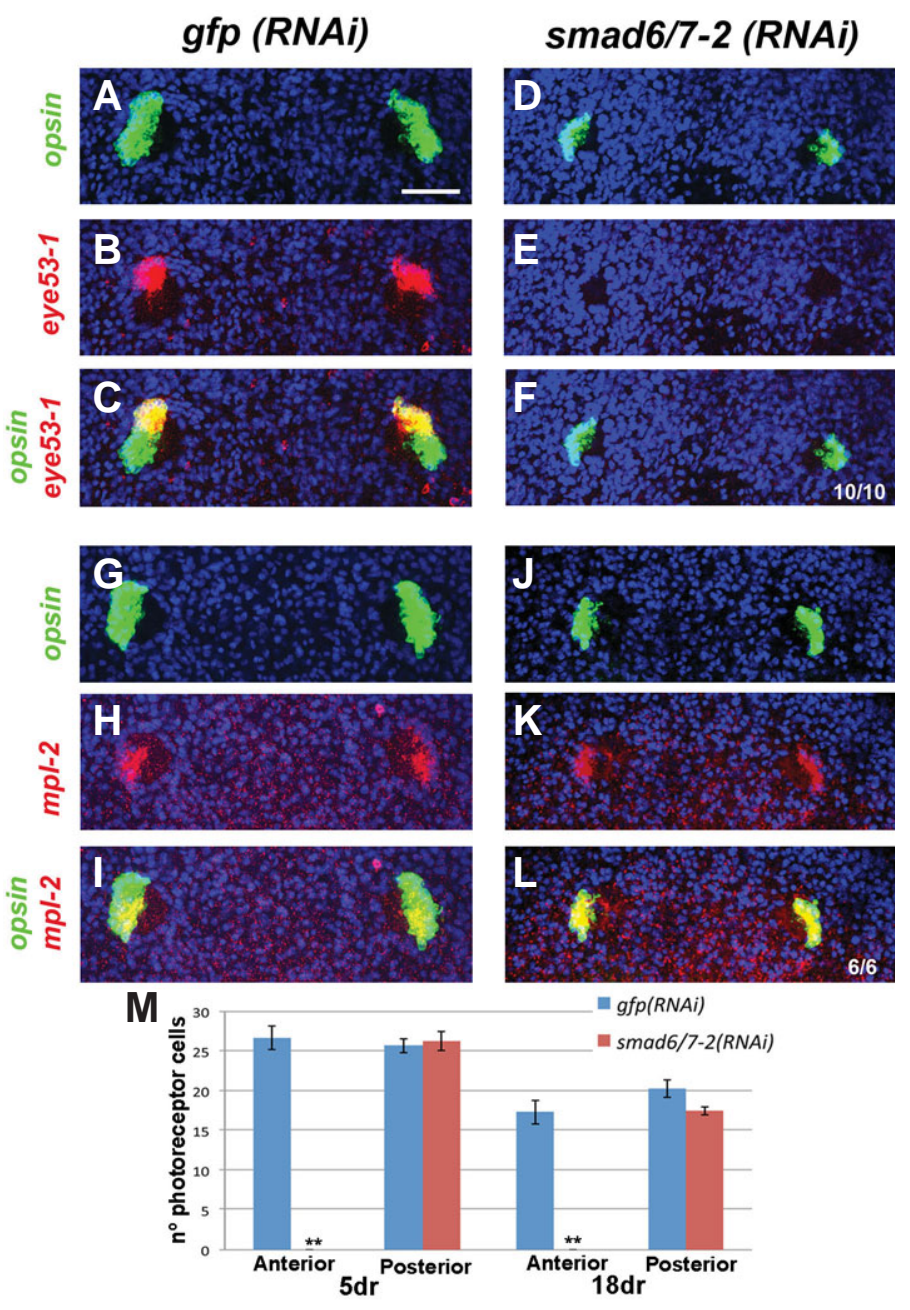

Fig. 6 (Right). Anterior subpopulation of photoreceptor cells disappears after inhibition of Smed-smad6/7-2. (A-F) Double fluorescent in situ hybridization against opsin (A,D) and the anterior marker eye53-1 (B,E). Note the disappearance of the domain of expression of eye53-1 in smad6/72(RNAi) planarians. (G-L) Double fluorescent in situ hybridization against opsin $(\mathbf{G}, \mathbf{J})$ and the posterior marker $\mathrm{mpl}-2(\mathbf{H}, \mathbf{K})$. Note that the expression domain of the posterior marker covers the whole expression domain of opsin in smad6/7-2(RNAi) planarians (L). (M) Graphical representation of the number of anterior and posterior photoreceptor cells at 5 and 18 days of regeneration in control and Smed-smad6/7-2(RNAi) planarians. ${ }^{*} p<0.001$ (t test). (A-L) Animals are shown at 10 days of regeneration. Anterior is to the top. Scale bar: $50 \mu \mathrm{m}$.

subpopulations, we analysed the expression of the anterior markers eye53-1 and npp-12, and the posterior markers eye53-2 and $m p l-2$ in smad6/7-2(RNAi) planarians.

No differences were observed in the expression of $m p l-2$ and eye53-2in the posterior population of photoreceptor cells compared to control organisms (red arrowheads in Fig. 5 A-D). However, in contrast, the expression of the anterior markers eye53-1 and npp-12 was completely absent in smad6/7-2(RNAi) animals (Fig. $5 \mathrm{E}-\mathrm{H})$.

The number of anterior and posterior photoreceptor cells was quantified by combining nuclear staining and double FISH for opsin and the anterior marker eye53-1 (Fig. $6 \mathrm{~A}-\mathrm{F}$ ) or the posterior marker mpl-2 (Fig. 6 G-L). Anterior eye53-1-positive cells were absent in smad6/7-2(RNAi) treated planarians since initial stages of regeneration ( 5 days of regeneration, $26.7 \pm 1.5$ cells in controls $[\mathrm{n}=7$ ] versus 0 cells in smad6/7-2(RNAi) eyes [ $\mathrm{n}=16] ; 18$ days of regeneration, $17.3 \pm 0.9$ cells in controls $[n=12]$ versus 0 cells in
smad6/7-2(RNAi) eyes [n=17]) (Fig. 6 B,E,M). On the other hand, the total number of $\mathrm{mpl}$-2-positive cells was normal compared to control organisms ( 5 days of regeneration, $25.7 \pm 1.1$ cells in controls $[\mathrm{n}=7$ ] versus $26.3 \pm 1.2$ cells in smad6/7-2(RNAi) eyes [ $\mathrm{n}=7] ; 18$ days of regeneration, $20.3 \pm 1.1$ cells in controls versus $17.5 \pm 0.5$ cells in smad6/7-2(RNAi) eyes [n=17]) (Fig. $6 \mathrm{H}, \mathrm{K}, \mathrm{M})$. Since all visual cells expressed both opsin and the posterior marker $\mathrm{mpl}-2$ after smad6/7-2 silencing (Fig. 4E), these results indicate that the reduction in total number of photoreceptors was based exclusively on the lack of the anterior subpopulation of eye53-1-positive cells.

Similar phenotypes were obtained in intact (non-regenerating) animals (Sup. Fig. 1). Twenty days after initial treatment, the eyes of smad6/7-2-silenced, uncut planarians appeared rounded, and both pigment and photoreceptor cells seemed to be reduced. Also, as happened during regeneration, the anterior population of photoreceptor cells disappeared (Sup. Fig. 1). Taken together, 

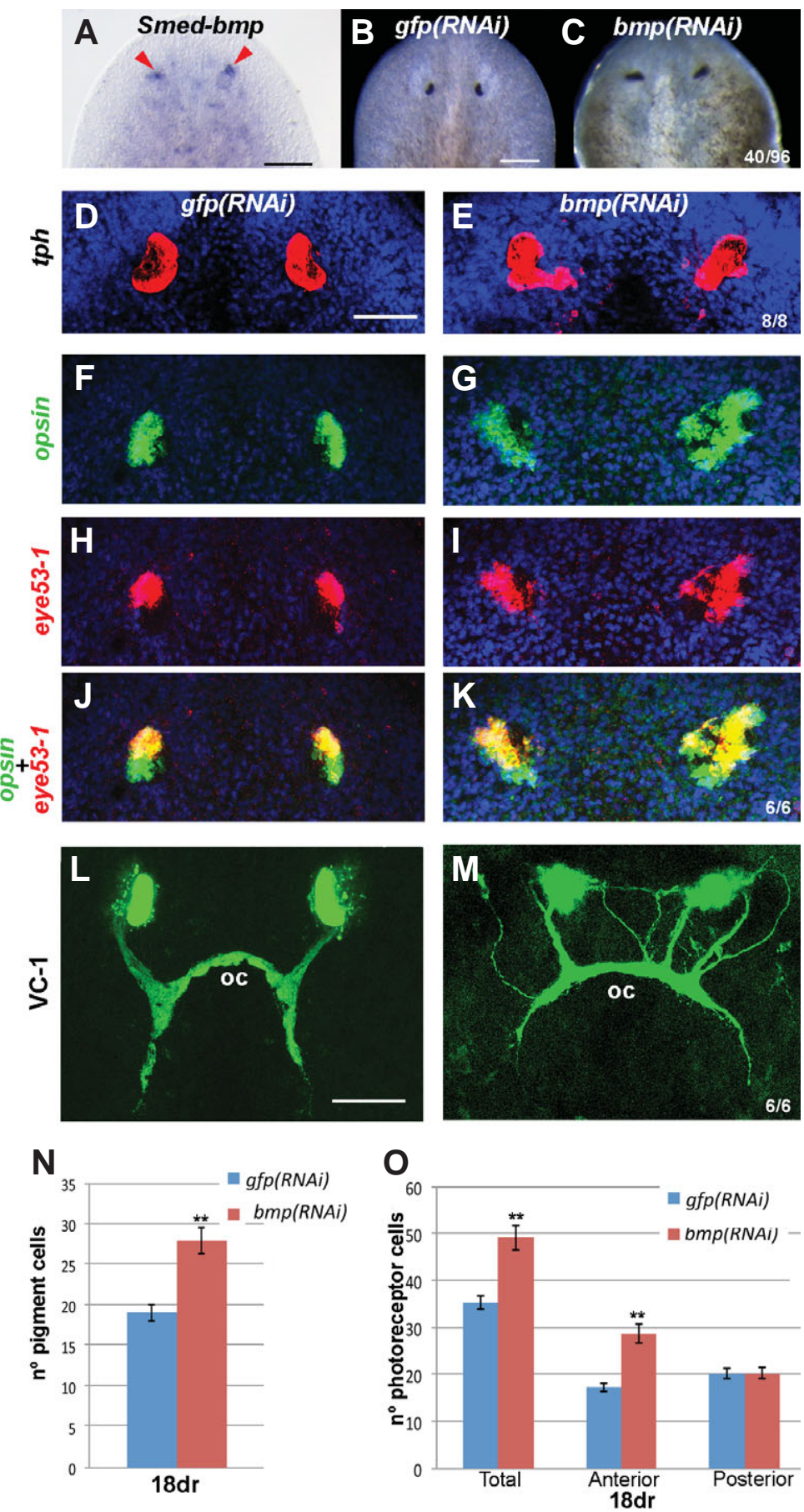

Fig. 7. Low doses of bmp RNAi result in expansion of pigment and anterior photoreceptor cells. (A) Smed-bmp expression (arrowheads) in the eyes of intact planarians. (B,C) Compared to control planarians (B), bmp(RNAi) animals have larger, elongated eyes (C). (D,E) tph fluorescent in situ hybridization. (F-K) Double fluorescent in situ hybridization against opsin (F,G) and the anterior marker eye53$1(\mathbf{H}, \mathbf{I})$. Note the expansion of the expression domain of eye53-1 in bmp(RNAi) animals. (L,M) Immunofluorescence againstarrestin (VC-1) showing disorganized visual axonal projections in bmp(RNAi) animals. (N) Graphical representation of the number of pigment cells in control and bmp(RNAi) planarians. (0) Graphical representation of the number of photoreceptor cells in control and bmp(RNAi) planarians. ${ }^{*} p<0.001$ (t test). (B-M) Animals shown at 18 days of regeneration. Anterior is to the top. oc, optic chiasm. Scale bars, (A-C) $200 \mu \mathrm{m}$; (D-M) $50 \mu \mathrm{m}$. these results suggest an essential role for Smed-smad6/7-2 activity in the specification and maintenance of the anterior subpopulation of eye photoreceptor cells.

\section{The anterior population of photoreceptor cells expands after low doses of bmp (RNAi)}

Loss of function of several elements of the BMP pathway disrupts regeneration of the planarian eyes, resulting in aberrant projections of the visual axons and supernumerary or fragmented eyes (Reddien et al., 2005a, 2007; Molina et al., 2007, 2011a; Orii and Watanabe, 2007). However, so far, only Djbmp, the homologue of bmp identified in the planarian species Dugesia japonica, has been found to be transiently expressed in the eyes at 6 days of regeneration (Mannini et al., 2008). We observed Smed-bmp expression in the eyes of intact $S$. mediterranea animals (Fig. 7A). Interestingly, the expression of Smed-bmp resembled that of Smed-smad6/7-2 and seemed to target an anterior population of photoreceptor cells (arrowheads in Fig. 7A). Unfortunately, due to the weak expression levels of both smad6/7-2 and bmp within the planarian eye, double smad6/7-2 and bmp FISH did not allow us to determine whether smad6/7-2 and bmp transcripts colocalize in the same cells.

To further characterize the eye phenotype associated with the loss of function of BMP signalling, we performed RNAi for Smed-bmp. Remarkably, we found that low doses of $b m p(R N A i)$ resulted in regeneration of larger, elongated pigmentary cups ( $n=40 / 96$, compare Fig. $7 B, C$ and $D, E)$ that contained a larger number of pigment cells $(19.1 \pm 1.0$ in controls [ $\mathrm{n}=7$ ] versus $28.0 \pm 1.6 \mathrm{in} b m p(R N A i)$ eyes $[\mathrm{n}=6])$ (Fig. $7 \mathrm{~N})$. Moreover, bmp(RNAi) animals had larger numbers of photoreceptor cells $(35.4 \pm 1.4$ in controls $[n=20]$ versus 49.2 2.6 in bmp(RNAi) eyes [ $=10]$ ) (Fig. 7 F, G,O). Most interestingly, the increased number of photoreceptor cells after low doses of $b m p(R N A i)$ was correlated with an increase in the anterior subpopulation of eye53-1-positive cells $(17.3 \pm 0.9$ in controls $[n=12]$ versus $28.8 \pm 2.0$ in bmp (RNAi) eyes $[\mathrm{n}=10]$ ) (Fig.7 $\mathrm{H}-\mathrm{K}, \mathrm{O})$, whereas there were no significant differences in the number of cells that constitute the posterior subpopulation compared to control organisms $(20.3 \pm 1.1$ in controls $[n=12]$ versus $20.0 \pm 1.2$ in bmp (RNAi) eyes $[\mathrm{n}=10])$ (Fig. 70). Finally, as previously reported (Molina et al., 2007), VC-1 immunostaining after bmp silencing showed that axonal projections appeared disorganized compared to controls (Fig. 7 L,M).

The complementary phenotypes observed in smad6/72(RNAi) and $b m p(R N A i)$ planarians suggest that the disappearance of eye53-1-labelled anterior photoreceptor cells after smad6/7-2 silencing might be linked to an increase on BMP pathway activity in this cell population. Taken together, these results support an essential role of BMP signalling in specifying the number of anterior photoreceptor cells.

\section{Discussion}

I-Smads are potent antagonists of the BMP and TGF $\beta$ signalling pathways (reviewed in Wrana, 2000). Whereas two I-Smads, Smad6 and Smad7, have been described in verte- 
brates, a single homologue is found in most invertebrate organisms. This study reports the isolation and functional characterization of the two I-Smad homologues in S. mediterranea: Smed-smad6/7-1 and Smed-smad6/7-2. Smed-smad6/7-1 and Smed-smad6/7-2 may have arisen by internal gene duplication within the planarian lineage, as occurred in other planarian gene families (Reddien et al., 2005b; Palakodeti et al., 2008; Molina et al., 2009).

Differences in the expression patterns of planarian I-Smads suggest that their functions might have diverged. The expression of smad6/7-1 in neoblasts, however, does not seem to be essential for stem cell survival and differentiation, as normal regeneration took place after smad6/7-1 silencing. Similarly, although the expression of smad6/7-2 in the CNS was especially interesting, since BMP signalling is known to act as a potent anti-neurogenic factor (reviewed in Harland, 2000), an apparently normal CNS regenerated after smad6/7-2 silencing. Finally, in contrast to what would be expected for an antagonist of BMP signalling, no dorsalized planarians were observed after either single or double I-Smad silencing. Several rounds of RNAi treatment and regeneration are necessary to obtain partially dorsalized planarians after silencing the antagonist noggin (Molina et al., 2011a). In order to further evaluate the role of I-Smads in DV axis establishment, therefore, it would be interesting to determine whether combinatorial noggins and smad6/7s silencing could give rise to stronger dorsalized planarians.

The BMP pathway is essential for development and regeneration of the vertebrate eye (Haynes et al., 2007). In mice, different threshold levels of BMP signalling regulate distinct developmental programs (Murali et al., 2004). Similarly, DPP signalling triggers the retinal developmental program in Drosophila (reviewed in Voas and Rebay, 2004). The complementary phenotypes obtained after smad6/7-2 silencing and low doses of bmp silencing support a role for this signalling pathway in planarian eye regeneration and maintenance. The anterior population of eye53-1-positive photoreceptor cells disappeared after upregulation of BMP signalling through RNAi of the inhibitor smad6/7-2, suggesting that higher levels of BMP signalling might disrupt the regeneration of this population of photoreceptor cells. In contrast, however, inhibition of the pathway by silencing the ligand bmp resulted in an increased number of eye53-1-positive photoreceptor cells. Neither smad6/7-2 nor bmp silencing altered the number of posterior photoreceptor cells, suggesting that the establishment of the correct number of this cell type does not rely on BMP signalling. Taken together, our results suggest that specific levels of BMP signalling are necessary for re-specification and maintenance of the correct number of anterior photoreceptor cells in planarians. Further experiments will be necessary to determine the signalling molecules involved in specifying the number of posterior photoreceptor cells.

Previous studies in the planarian $D$. japonica have suggested that pigment and photoreceptor cells derive from common progenitor cells that express terminal differentiation markers of both cell types (Takeda et al., 2009). On the other hand, however, it has recently been shown that pigment and photoreceptor cell lineages can be separately traced from neoblasts in S. mediterranea and so they exist as distinct progenitor populations prior to terminal differentiation and aggregation in the eye (Lapan and Reddien, 2011). Although not completely contradicting the previous hypothesis, these results suggest an independent origin. Apart from this area of uncertainty, it seems clear that pigment and photoreceptor cells must interact to form and maintain the correct structure of the eye. A reduction in number of pigment cells after egfr1-(RNAi), for instance, is accompanied by a disorganization of photoreceptor cells (Fraguas et al., 2011). This disorganization, however, does not alter the number of photoreceptor cells (Fraguas et al., 2011). On the other hand, our data suggest that the variation in the number of photoreceptor cells could modulate the number of pigment cells. smad6/7-2 silencing resulted in disappearance of the anterior population of eye53-1-positive cells and, consequently, a reduction in the total number of photoreceptor cells from early stages of regeneration. In contrast, pigment cells differentiated normally at 5 days of regeneration, but they started to diminish in number as regeneration proceeded, in parallel to the appearance of morphologically smaller and rounded pigment cups. Reciprocally, the increase in number of anterior photoreceptor cells after bmp(RNAi) was accompanied by a higher number of pigment cells. The delay in reduction of pigment cells observed after smad6/7-2(RNAi) suggest that the variation in the number of photoreceptor cells might induce the pigment cup to reorganize and adjust the cell number. Thereby, the change in the number of pigment cells could be a consequence of the variation in the number of anterior photoreceptor cells rather than a direct effect of smad6/7-2 or bmp silencing. Further experiments would be necessary to understand how pigment and photoreceptor cell number are coordinated during planarian eye regeneration.

\section{Materials and Methods}

\section{Organisms and gene nomenclature}

Planarians used in these experiments belong to an asexual biotype of S. mediterranea, of the clonal line $\mathrm{BCN}-10$ collected from an artificial spring in Montjuïc, Barcelona, Spain. The animals were maintained at $20^{\circ} \mathrm{C}$ in a 1:1 (v/v) mixture of distilled water and tap water treated with AquaSafe (TetraAqua, Melle, Germany). Animals were fed with organic veal liver and starved for at least a week before the experiments. Planarians 2 to $6 \mathrm{~mm}$ in length were used for all experiments. Genes and RNAi experiments were named using the nomenclature proposed by Reddien et al. (2008).

\section{Isolation of S. mediterranea inhibitory Smads}

I-Smad proteins from different animals were used to carry out tblastn searches on the genome assembly (v3.1, Washington University Sequencing Center, available at http://www.genome.wustl.edu) and the 454 transcriptome (Abril et al., 2010) of $S$. mediterranea. Sets of specific primers were designed to amplify predicted Smed-smad6/7-1 and Smed-smad6/7-2 homologues from cDNA made from total RNA using Superscript III (Invitrogen). The corresponding full-length transcripts were amplified by rapid amplification of cDNA ends (RACE) using the Invitrogen GeneRacer Kit (Invitrogen). GenBank accession numbers: Smed-smad6/7-1, JQ278719 and Smed-smad6/7-2, JQ278720.

\section{RNAi analysis}

Double-stranded RNAs (dsRNAs) for Smed-smad6/7-1, Smedsmad6/7-2 and Smed-bmp were synthesized by in vitro transcription (Roche) as described previously (Sánchez Alvarado and Newmark, 1999). dsRNA microinjections were performed as described elsewhere (Sánchez Alvarado and Newmark, 1999) following the standard protocol of a 32 $\mathrm{nl}$ injection of dsRNA on three consecutive days. Smed-smad6/7-1 and Smed-smad6/7-2 dsRNA were injected at a concentration of $600 \mathrm{ng} / \mu \mathrm{l}$, whereas dsRNA for Smed-bmp was injected at $250 \mathrm{ng} / \mu \mathrm{l}$. Control animals were injected with dsRNA corresponding to GFP, a gene not found on the genome of $S$. mediterranea. For regeneration experiments, animals were amputated pre- and postpharyngeally 3 days after the first injection and allowed to regenerate. Unless otherwise indicated, all the results presented 
refer to regenerating trunk pieces. To analyse the function of I-Smads during normal planarian homeostasis, intact uncut animals were re-injected 2 weeks after the first round of injections and analyzed 10 days after the second round of injections.

\section{Irradiation}

Intact planarians were $\gamma$-irradiated at 100 Grays (1.66 Gy/minute) with a Gammacell 1000 [Atomic Energy of Canada Limited] (Saló and Baguñà, 1985 ) and fixed for in situ hybridization 3 days after irradiation.

\section{In situ hybridization}

Whole mount in situ hybridizations were performed in an In situ Pro hybridization robot (Abimed/Intavis) as previously described (Molina et al., 2007, Umesono et al., 1997). For double FISH, animals were treated as described elsewhere (Pearson et al., 2009). Intact animals were processed for in situ hybridizations on paraffin sections as described previously (Cardona et al., 2005; Handberg-Thorsager and Saló, 2007). The following digoxigenin or fluorescein-labeled riboprobes were synthesized using an in vitro transcription kit (Roche): Smed-smad6/7-1 and Smed-smad6/7-2 (novel); Smed-eye53-1 (Zayas et al., 2005); Smed-eye53-2, Smed-mpl-2 and Smed-npp-12 (Collins et al., 2010); Smed-bmp (Molina et al., 2007); Smed-tph (Fraguas et al., 2011) and Smed-opsin (Sánchez Alvarado and Newmark, 1999). Samples were observed through Leica MZ16F and Zeiss Stemi SV6 stereomicroscopes and a Zeiss Axiophot microscope; images were captured with a Nikon Coolpix E995 or Leica DFC300FX camera. Confocal laser scanning microscopy was performed with a Leica SP2.

\section{Whole-mount immunostaining}

Immunostaining was carried out essentially as described previously (Cebrià and Newmark, 2005). Anti-arrestin (VC-1) monoclonal antibody, which specifically recognized planarian photoreceptor cells, was used at dilution of 1/15,000 (Sakai et al., 2000). Highly cross-absorbed Alexa Fluor 488-conjugated goat anti-mouse lgG secondary antibody (Molecular Probes) was used at dilution of 1:400. Confocal laser scanning microscopy was performed with a Leica SP2.

\section{Phototactic assay}

Phototactic assay was carried out using a modified version of the method described by Inoue et al. (2004). Planarian behaviour was recorded for 180 seconds using an overhead digital video camera (Canon EOS550D). The behaviour analysis software SMART v.2.5.21 (Panlab, Spain) was used to quantify the time spent by the animals in each of the three virtual subdivisions of the transparent container of $60 \times 30 \times 10 \mathrm{~mm}$, filled with $10 \mathrm{ml}$ of planarian water. To obtain a light gradient, the container was protected by a black screen with a hole that allows the entrance of 500 lux of white light from one side of the container.

\section{Acknowledgements}

We would like to thank Francesc Cebrià and Marta Iglesias for critical reading of the manuscript, Dr. Hidefumi Orii and Prof. Kenji Watanabe for providing VC-1 and all members of the E. Saló, F. Cebrià, R. Romero and J.F. Abril groups for helpful discussions. We also thank Dr. lain Patten for editorial advice. This work was supported by grant BFU2008-01544 from the Ministerio de Educación y Ciencia (MEC), Spain, and grant 2009SGR1018 (AGAUR) to E.S.; A.G-S. received a Master Fellowship from Caja España and a Beca de colaboración from the Ministerio de Educación; M.D.M. received an FPU fellowship from the Ministerio de Educación.

\section{References}

ABRIL, J.F., CEBRIÀ, F., RODRÍGUEZ-ESTEBAN, G., HORN, T., FRAGUAS, S., CALVO, B., BARTSCHERER, K., SALÓ, E. (2010). Smed454 dataset: unravelling the transcriptome of Schmidtea mediterranea. BMC Genomics 11: 731.

CARDONA, A., FERNÁNDEZ, J., SOLANA, J., ROMERO, R. (2005). An in situ hybridization protocol for planarian embryos: monitoring myosin heavy chain gene expression. Dev Genes Evol 215: 482-488

CEBRIÀ, F., NEWMARK, P.A. (2005). Planarian homologs of netrin and netrin receptor are required for proper regeneration of the central nervous system and the maintenance of nervous system architecture. Development 132: 3691-3703.

COLLINS, J.J., HOU, X., ROMANOVA, E.V., LAMBRUS, B.G., MILLER, C.M., SABERI, A., SWEEDLER, J.V., NEWMARK P.A. (2010). Genome-wide analyses reveal a role for peptide hormones in planarian germline development. PLOS Biology 8, e1000509.

DUBOIS, F. (1949). Contribution à l'étude de la migration des cellules de regeneration chez les planaires dulcicoles. Bull Biol Fr Belg 83: 213-283.

EISENHOFFER, G.T., KANG, H., SÁNCHEZALVARADO,A. (2008). Molecular analysis of stem cells and their descendants during cell turnover and regeneration in the planarian Schmidtea mediterranea. Cell Stem Cell 11: 327-339.

FRAGUAS, S., BARBERÁN, S., CEBRIÀ, F. (2011). EGFR signalling regulates cell proliferation, differentiation and morphogenesis during planarian regeneration and homeostasis. Dev Biol 354: 87-101.

HANDBERG-THORSAGER, M., SALÓ, E. (2007). The planarian nanos-like gene Smednos is expressed in germline and eye precursor cells during development and regeneration. Dev Genes Evol 217: 403-411.

HANDBERG-THORSAGER, M., FERNÁNDEZ E., SALÓ, E. (2008). Stem cells and regeneration in planarians. Front Biosci 13: 6374-6394

HARLAND, R. (2000). Neural induction. Curr Opin Genetics Dev 10: 357-362.

HAYNES, H., GUTIÉRREZ, C., AYCINENA, JC, TSONIS, P.A., DEL RIO-TSONIS, K (2007). BMP signaling mediates stem/progenitor cell-induced retina regeneration. Proc Natl Acad Sci USA 104: 20380-20385.

INOUE, T., KUMAMOTO, H., OKAMOTO, K., UMESONO, Y., SAKAI, M., SÁNCHEZ ALVARADO A., AGATA, K. (2004). Morphological and functional recovery of the planarian photosensing system during head regeneration. Zool Sci 21: 275-283.

LAPAN, S.W., REDDIEN, P.W. (2011). dlx and sp6-9 control optic cup regeneration in a prototypic eye. PLOS Genetics 7: e1002226.

LITTLE, S.C., MULLINS, M.C. (2006). Extracellular modulation of BMP activity in patterning the dorsoventral axis. Birth Defects Research (Part C) 78: 224-242.

LIU, A., NISWANDER, L.A. (2005) Bone morphogenetic protein signalling and vertebrate nervous system development. Nature Rev Neurosci 6: 945-954.

MANNINI, L., ROSSI, L., DERI, P., GREMIGNI, V., SALVETTI,A., SALÓ, E., BATISTONI, R. (2004). Djeyes absent (Djeya) controls prototypic planarian eye regeneration by cooperating with the transcription factor Djsix-1. Dev Biol 269: 346-359.

MANNINI, L., DERI, P., GREMIGNI, V., ROSSI, L., SALVETTI, A., BATISTONI, R. (2008). Two $m s h / m s x$-related genes, Djmsh1 and Djmsh2, contribute to the early blastema growth during planarian head regeneration. Int J Dev Biol 52: 943-952.

MOLINA, M.D., SALÓ, E., CEBRIÀ, F. (2007). The BMP pathway is essential for re-specification and maintenance of the dorsoventral axis in regenerating and intact planarians. Dev Biol 311: 79-94.

MOLINA, M.D., SALÓ, E., CEBRIÀ, F. (2009). Expression pattern of the expanded noggin gene family in the planarian Schmidtea mediterranea. Gene Expr Patterns 9: 246-253.

MOLINA, M.D., NETO, A., MAESO, I., GÓMEZ-SKARMETA, J.L., SALÓ, E., CEBRIÀ, F. (2011a). Noggin and Noggin-Like genes control dorsoventral axis regeneration in planarians. Curr Biol 21: 300-305.

MOLINA, M.D., SALÓ, E., CEBRIÀ, F. (2011b). Organizing the DV axis during planarian regeneration. Commun Integr Biol 4: 498-500.

MURALI, D., YOSHIKAWA, S., CORRIGAN, R.R., PLAS, D.J., CRAIR, M.C., OLIVER, G., LYONS, K.M., MISHINA, Y., FURUTA, Y. (2004). Distinct developmental programs require different levels of Bmp signalling during mouse retinal development. Development 132: 913-923.

OKAMOTO, K., TAKEUCHI, K., AGATA, K. (2005). Neural projections in planarian brain revealed by fluorescent dye tracing. Zoolog Sci 22: 535-546.

ORII, H., KATAYAMA, T., SAKURAI, T., AGATA, K., WATANABE, K. (1998). Immunohistochemical detection of opsins in turbellarians. Hydrobiologia 383: 183-187.

ORII, H., WATANABE, K. (2007). Bone morphogenetic protein is required for dorsoventral patterning in the planarian Dugesiajaponica. Dev Growth Differ 49:345-349.

PALAKODETI, D., SMIELEWSKA, M., LU, Y.C., YEO, G.W., GRAVELEY, B.R. (2008) The PIWI proteins SMEDWI-2 and SMEDWI-3 are required for stem cell function and piRNA expression in planarians. RNA 14: 1174-1186. 
PEARSON, B.J., EISENHOFFER, G.T., GURLEY, K.A., RINK, J.C., MILLER, D.E., SÁNCHEZ ALVARADO, A. (2009). Formaldehyde-based whole mount in situ hybridization method for planarians. Dev Dyn 238: 443-450.

PINEDA, D., GONZÁLEZ, J., CALLAERTS, P., IKEO, K., GEHRING, W.J., SALÓ, E. (2000). Searching for the prototypic eye genetic network: sine oculis is essential for eye regeneration in planarians. Proc Natl Acad Sci USA 97: 4525-4529.

PINEDA, E., ROSSI, L., BATISTONI, R., SALVETTI, A., MARSAL, M., GREMIGNI, V., FALLENI, A., GONZÁLEZ-LINARES, J., DERI, P., SALÓ, E. (2002). The genetic network of prototypic planarian eye regeneration is Pax6 independent. Development 129: 1423-1434.

QUILLIEN, A., BLANCO-SÁNCHEZ, B., HALLUIN, C., MOORE, J.C., LAWSON, N.D., BLADER, P., CAU, E. (2011). BMP signaling orchestrates photoreceptor specification in the zebrafish pineal gland in collaboration with Notch. Development 138: 2293-2302.

REDDIEN, P.W., BERMANGE, A. L., MURFITT, K.J., JENNINGS, J.R., SÁNCHEZ ALVARADO, A. (2005a). Identification of genes needed for regeneration, stem cell function, and tissue homeostasis by systematic gene perturbation in planaria. Dev Cell 8: 635-649.

REDDIEN, P.W., OVIEDO, N.J., JENNINGS, J.R., SÁNCHEZALVARADO, A. (2005b). SMEDWI-2 is a PIWI-like protein that regulates planarian stem cells. Science 310: $1327-1330$.

REDDIEN, P.W., BERMANGE, A. L., KICZA, A.M., SÁNCHEZALVARADO, A. (2007). BMP signaling regulates the dorsal planarian midline and is needed for asymmetric regeneration. Development 134: 4043-4051.

REDDIEN, P.W., NEWMARKP.A., SÁNCHEZALVARADO,A. (2008). Gene nomenclature guideline for the planarian Schmidtea mediterranea. Dev Dyn237: 3099-3101.

SAKAI, F., AGATA, K., ORII, H., WATANABE, K. (2000). Organization and regeneration ability of spontaneous supernumerary eyes in planarians - Eye regeneration field and pathway selection by optic nerves. Zool Sci 17: 375-381.
SALÓ, E. BAGUÑÀ, J. (1985). Cell movement in intact and regenerating planarians. Quantitation using chromosomal, nuclear and cytoplasmic markers. J Embryol Exp Morphol 89: 57-70.

SALÓ, E. (2006). The power of regeneration and the stem-cell kingdom: freshwater planarians (platyhelminthes). Bioessays 28: 546-559.

SALÓ, E., BATISTONI, R. (2008). The planarian eye: a simple and plastic system with great regenerative capacity. In "Animal models in eye research" (P. A. Tsonis, Ed.), pp. 15-26) Elsevier Academic Press.

SÁNCHEZ ALVARADO, A., NEWMARK, P.A. (1999). Double-stranded RNA specifically disrupts gene expression during planarian regeneration. Proc Natl Acad Sci USA 96: 5049-5054.

SJÖDAL, M., EDLUND, T., GUNHAGA, L. (2007). Time of exposure to BMP signals plays a key role in the specification of the olfactory and lens placodes ex vivo. Dev Cell 13: 141-149.

TAKEDA, H., NISHIMURA, K., AGATA, K. (2009). Planarians maintain a constant ratio of different cell types during changes in body size by using the stem cell system. Zool Sci 26: 805-813.

UMESONO, Y., WATANABE, K., AGATA, K. (1997). A planarian orthopedia homolog is specifically expressed in the branch region of both the mature and regenerating brain. Dev Growth Differ 39: 723-727.

VOAS, M.G., REBAY, I. (2004). Signal integration during development: insights from the Drosophila eye. Dev Dyn 229: 162-175.

WRANA, J.L. (2000). Crossing Smads. Sci STKE 2000: re1.

ZAYAS, R.M., HERNÁNDEZ, A., HABERMANN, B., WANG, Y., STARY, J.M., NEWMARK, P.A. (2005). The planarian Schmidtea mediterranea as a model for epigenetic germ cell specification: analysis of ESTs from the hermaphroditic strain. Proc. Natl. Acad. Sci. USA 102: 18491-18496.

ZHAO, S., CHEN, Q., HUNG, F-C., OVERBEEK, P.A. (2002). BMP signaling is required for development of the ciliary body. Development 129: 4435-4442. 


\section{Further Related Reading, published previously in the Int. J. Dev. Biol.}

Planarian regeneration: achievements and future directions after 20 years of research Emili Saló, Josep F. Abril, Teresa Adell, Francesc Cebriá, Kay Eckelt, Enrique Fernández-Taboada, Mette Handberg-Thorsager, Marta Iglesias, M Dolores Molina and Gustavo Rodríguez-Esteban

Int. J. Dev. Biol. (2009) 53: 1317-1327

Expression of a retinal homeobox $(\mathbf{R x})$ gene during planarian regeneration Linda Mannini, Paolo Deri, Jacopo Picchi and Renata Batistoni Int. J. Dev. Biol. (2008) 52: 1113-1117

Two $\mathrm{msh} / \mathrm{msx}$-related genes, Djmsh1 and Djmsh2, contribute to the early blastema growth during planarian head regeneration

Linda Mannini, Paolo Deri, Vittorio Gremigni, Leonardo Rossi, Alessandra Salvetti and Renata Batistoni

Int. J. Dev. Biol. (2008) 52: 943-952

From Planarians to Mammals - the many faces of regeneration

Jerzy Moraczewski, Karolina Archacka, Edyta Brzoska, Maria-Anna Ciemerych, Iwona Grabowska, Katarzyna Janczyk-Ilach, Wladyslawa Streminska and Malgorzata Zimowska Int. J. Dev. Biol. (2008) 52: 219-227

The genetic control of eye development and its implications for the evolution of the various eye-types

Walter J Gehring

Int. J. Dev. Biol. (2002) 46: 65-73

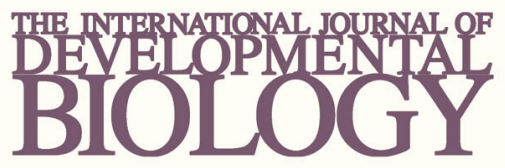

Volume 54 Nos. 6/7
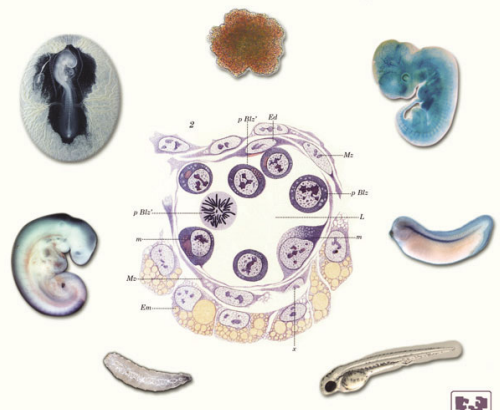

Developmental Hematopoiesis
5 yr ISI Impact Factor $(2010)=2.961$

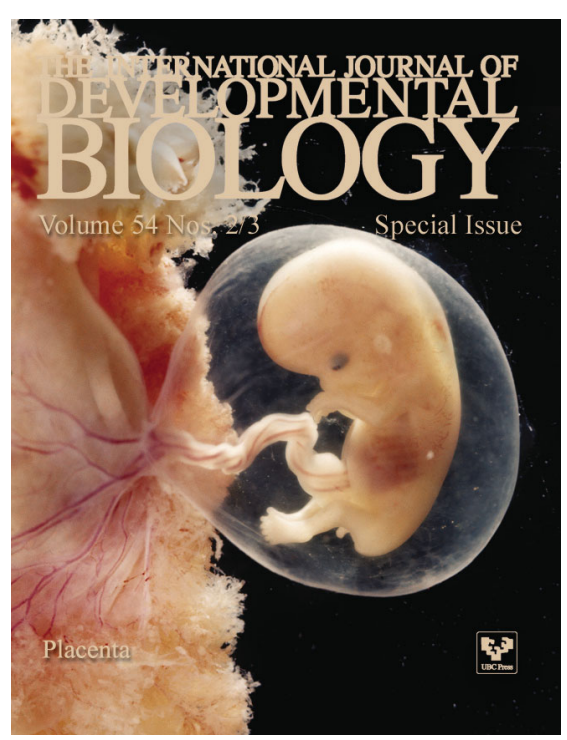

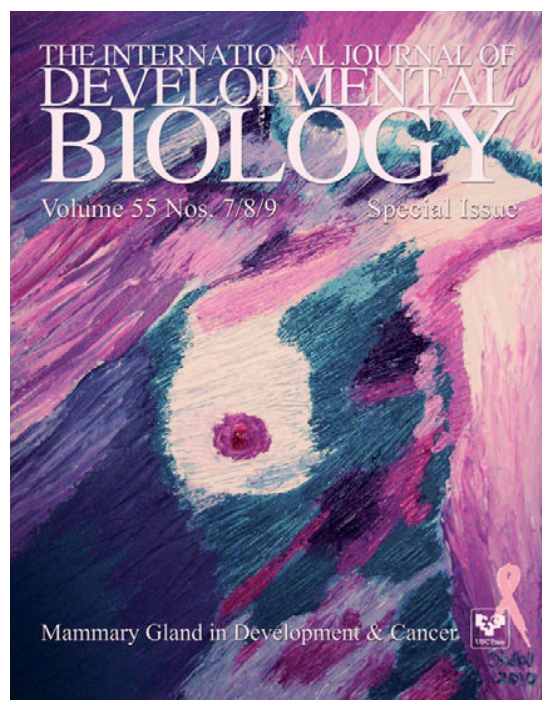

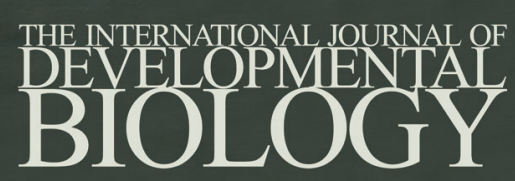

Volume 55 Nos. $4 / 5$

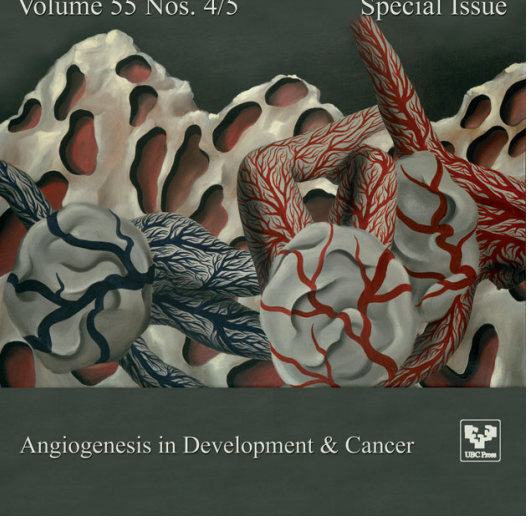

